\title{
A ATUALIDADE DA UTOPIA NA \\ PERSPECTIVA DE ERNST BLOCH
}

\section{THE ACTUALITY OF UTOPIA ON THE PERSPECTIVE OF ERNST BLOCH}

Recebido em 08 de agosto de 2019

Ivo Marcos Theis ${ }^{1}$

https://orcid.org/0000-0003-0128-2188 http://lattes.cnpq.br/2063932952182790

Aprovado em 17 de Dezembro de 2019

RESUMO: Neste artigo se procura oferecer uma leitura sobre utopia, em especial, sobre a atualidade da utopia a partir de Ernst Bloch. São seis as sessões em que o artigo está estruturado: à introdução segue uma segunda sessão na qual se apresenta a utopia na vida e na obra de Bloch; a terceira sessão é consagrada à utopia como ela pode ser identificada em "O princípio esperança"; na quarta se dedica atenção à atualidade da noção de utopia segundo Bloch, com especial destaque para a sua relativamente pouco conhecida teoria da assincronia; a quinta seção trata de algumas reconhecidas divergências e alguns pouco mencionados mal-entendidos; e, por fim, a última é destinada à conclusão. Palavras-chave: Ernst Bloch; Princípio Esperança; utopia concreta.

\begin{abstract}
In this article I would like to offer a reading on utopia, especially on the actuality of utopia from the perspective of Ernst Bloch. The article is structured in six parts: after the introduction follows a second part in which utopia is presented in the life and work of Bloch; the third part is devoted to utopia as it can be identified in "The Principle of Hope"; in the fourth part is paid attention to the actuality of the notion of utopia according to Bloch with special emphasis on its relatively little known "theory of asynchrony"; the fifth part deals with some recognized divergences and some little mentioned misunderstandings; and finally the latter part is destined for the conclusion.
\end{abstract}

Keywords: Ernst Bloch: The Principle of Hope; utopia.

\section{INTRODUÇÃO}

Neste início de século XXI a humanidade parece estar não mais próxima, mas mais distante disso que se poderia chamar de emancipação - o fim de toda opressão, de toda tirania, de toda dominação. Se movermos nossa lupa em direção às formações sociais periféricas, o quadro parece ainda mais grave. No âmbito da periferia, a América Latina parecia encaminhar-se, nos anos 2000, para a recuperação da dignidade - perdida durante a longa noite escura que sobre grande parte dela se abateu, principalmente, entre os anos 1960 e 1980, e postergada pela selvageria ultraliberal do Consenso de Washington,que lhe foi imposta nos anos 1990. Que dúvidas há que, nos anos 2010, o neoliberalismo ressurgiu no subcontinente(FERNÁNDEZ, 2016) com renovada virulência? Mesmo o gigante Brasil - frequentemente empenhado em curvar-se diante das formações sociais centrais, eternamente embalado pela obsessão de suas elites alienadas de integrar o país ao "primeiro mundo" - tem experi-

\footnotetext{
${ }^{1}$ Economista, doutor em Geografia (Universität Tübingen), com pós-doutorado em Política Científica e Tecnológica (Unicamp) e Desenvolvimento Regional (UNISC), professor e pesquisador do Programa de Pós-Graduação em Desenvolvimento Regional / Universidade Regional de Blumenau, bolsista de Produtividade em Pesquisa 2 do CNPq. E-mail: theis@furb.br.
} 
mentado regressões espantosas em face de avanços sociais e políticos duramente conquistados nos anos 2000. Talvez se deva mesmo voltar a empregar o termo barbárie para caracterizar a época atual.

Por isso, parece conveniente recorrer a uma perspectiva temporal mais ampla. Assim procedendo - mas, sem perder de vista os pesados fatos do presente - pode-se colocar a conjuntura no seu lugar mais apropriado, a considera-la como um momento, entre tantos, que enfeixam uns nos outros em um tempo histórico não linear. A perspectiva que aqui se adota repousa, ademais, em um duplo movimento: de um lado, bisbilhotar o passado, quando necessário, em busca de esperança e redenção; de outro, tomar o próprio passado como algo com o que se deva, definitivamente, romper.

Alguns eventos, como revoluções sociais - em 2019 comemoram-se os 230 anos da Revolução Francesa e os 60 anos da Revolução Cubana -, mostram que a história fornece boas evidências de que lá onde grassava a barbárie, exatamente, lá onde já não se identificava mais nenhum laivo de esperança, lá emergiu algo extraordinariamente diferente que ainda não existiu - o novum. Contudo, também parece correto ver esses raros eventos como relâmpagos, que irrompem de um céu, habitualmente, pesado e encoberto, mas que, não obstante, iluminam o que se oculta na paisagem cinzenta e, aparentemente, imutável.

Outro desses raros fenômenos que deixou rastros indeléveis na paisagem é a obra de Ernst Bloch, um autor prolífico que escreveu e publicou, continuamente, entre 1918 e 1975.Se as revoluções sociais podem ser consideradas momentos significativos de recuperação da consciência e redenção, momentos que recordam a interrupção do fluxo da barbárie (portanto, a cessação da repetição indefinida de opressão, tirania e dominação), se, enfim, apontam para a concretização da utopia, o momento da publicação de sua opus magna - o terceiro e último volume de Das Prinzip Hoffnung [“O princípio esperança”] veio à luz em 1959, portanto, no mesmo ano em que ocorreu a Revolução Cubana, há 60 anos atrás - não será, por qualquer motivo, de menor significação.

O tema da utopia - isto é, o não [ón] lugar [tópos] - mereceu atenção de inúmeros estudiosos e ativistas, tanto antes de Thomas Morus [1480-1535] quanto depois dele. Entretanto, talvez não haja quem o tenha levado tão a sério e tão longe quanto o filósofo da utopia (BROCA, 2014; KROTZ, 2011).O propósito que se tem em vista é tratar da utopia desde a obra de Bloch, em especial, recuperar a noção de utopia presente em "O princípio esperança" e examinar sua atualidade no presente contexto de exacerbação da barbárie.

Convém assinalar que a obra de Ernst Bloch é pouco conhecida no Brasil e, possivelmente, também, nos demais países de língua portuguesa.Excetuando-se seu "O princípio esperança", cujos três volumes foram publicados apenas a partir de 2005, somente "Thomas Münzer: teólogo da revolução" havia sido publicado antes, em 1973. Em países de língua espanhola, sua obra, talvez, seja mais conhecida, embora pareça improvável que esteja muito mais difundida. O que já sugeriria um questionamento quanto ao seu alcance na periferia, em especial, na América Latina. Em consequência, cabe outra questão: a de se Ernst Bloch tem, a rigor, algo a dizer para a América Latina e para a periferia. Conquanto sua obra tenha uma abrangência, por assim dizer, universal, a hipótese - que não poderá ser testada aqui - éde que grande parte da mensagem que ela embute poderia ter sido endereçada à América Lati$\mathrm{na}^{2}$. Voltando ao Brasil:salvo referências e publicações mais curtas e isoladas, a obra de Ernst

${ }^{2}$ Embora não se deva esquecer que, "En América Latina, Ernst Bloch ha estado poco presente en la discusión filosófica” (KROTZ, 2011, p. 71).

PRACS: Revista Eletrônica de Humanidades do Curso de Ciências Sociais da UNIFAP 
Bloch foi apresentada em uma escala mais abrangente e didática bastante tarde pelo suíço Pierre Furter (1974). Em anos mais recentes, uma contribuição também significativa viria da lavra do alemão-francês Arno Münster (1993; 1997). Ambos, contudo, tiveram seus escritos traduridos. Da parte de estudiosos brasileiros, o primeiro e, até o presente, mais notável esforço de disseminação das ideias de Bloch no Brasil foi levado a efeito por Suzana Albornoz (1999, 2002, 2006a).

Aqui se tentará, enfim, oferecer uma leitura sobre utopia e, em especial, sobre a atualidade da utopia a partir de Ernst Bloch. Seis são as sessões em que o artigo está estruturado: a esta introdução segue uma segunda sessão na qual se apresenta a utopia na vida e na obra de Bloch; a terceira sessão é consagrada à utopia como ela pode ser identificada em "O princípio esperança"; na quarta se dedica atenção à atualidade da noção de utopia segundo Bloch, com destaque para a sua relativamente pouco conhecida teoria da assincronia; a quinta seção trata de algumas reconhecidas divergências e alguns pouco mencionados mal-entendidos; e, por fim, a última é destinada ao que se costuma chamar de conclusão.

\section{A UTOPIA NA VIDA E NA OBRA DE ERNST BLOCH}

Talvez seja necessário, a quem busque aproximar-se de sua vida e obra, reconhecerem Ernst Bloch alguém que integra um conjunto muito reduzido de seres humanos "cuja vida e pensamento se gestam e desenvolvem em interação recíproca” (ALBORNOZ, 2006a, p. 14).Isso indica que se está diante de uma figura que, tanto quanto pensou o que viveu ao longo de seus 92 anos, também viveu intensamente aquilo que pensou (MÜNSTER, 1993; idem, 1997; WEIGAND, 1998).

Ernst Bloch nasceu, filho único de pais [Max e Berta Bloch]judeus não praticantes, na cidade industrial de Ludwigshafen, próximo a Mannheim, Alemanha, em 8 de julho de 1885, falecendo na cidade de Tübingen, também Alemanha, em 4 de agosto de 1977. Sua passagem pela escola não foi das mais agradáveis. Dotado de memória invejável, logo passou a interessar-se por literatura e filosofia antiga e moderna. A partir de 1905, Ernst Bloch estudaria Filosofia como curso principal [Hauptfach], optando por Física, Música (consta ter sido exímio pianista até o fim de sua vida) e Germanística como cursos complementares [Nebenfächer], na Universidade de Munique. Posteriormente, mudaria para Würzburg, onde concluiria seu doutorado em 1908, com uma tese em que criticou a divisão neokantiana entre as ciências da natureza e da cultura.

Nos anos seguintes viveu em diversas cidades alemãs e conheceu outros países da Europa. Em Berlim assistiu a um seminário de Georg Simmel [1858-1918] e em Heidelberg frequentou o círculo em torno a Max Weber [1864-1920]. Desde esta época cultivaria estreita amizade com György Lukács [1885-1971]. Em 1913 casou com Else von Strizky, vivendo com ela em Munique. Aí escreveu,entre abril de 1915 e maio de 1917, sua primeira obra de maior fôlego, Geist der Utopie ["Espírito da Utopia”] - que foi publicada em 1918. Apenas cinco anos depois, em 1923, Bloch publicaria uma edição revista. Nela, em síntese,anunciaria o que acabaria aprofundando extraordinariamente ao longo de toda a sua vida (SCHMIEDKOWARZIK, 1995). E o que exatamente é isso que aí anuncia? Em resumidas palavras: "Quer-se ser diferente em torno de nós. Contudo, ainda não aconteceu nada" . Mas, como se pode constatar a seguir, o que, de fato, aí anuncia, em termos bem mais precisos, é sua

3 “Es will um uns anders werden. Aber noch hat sich nichts geschieden" (BLOCH, 1918, p. 295).

PRACS: Revista Eletrônica de Humanidades do Curso de Ciências Sociais da UNIFAP 
preocupação em desvelar a tendência utópica incrustrada na realidade:

"que seremos bem-aventurados, que o reino dos céus possa existir, que o evidentemente reconhecido conteúdo do sonho da alma humana também se assente, que uma esfera como sempre de determinada realidade lhe esteja correspondentemente confrontada, isto não apenas é pensável (isto é, formalmente possível), ou realizável (isto é, objetivamente possível), mas simplesmente necessário, muito longe de todas as comprovações, demonstrações, permissões e premissas, formais ou reais, de sua existência, postulada a priori desde a natureza da coisa e, por conseguinte, também, verdadeira, isto é, da tendência utópica e intensiva da realidade exatamente dada, essencial"4.

Ainda em 1917 acabaria emigrando para a Suíça, de onde passaria a escrever contra a Primeira Guerra Mundial e o militarismo do império alemão. Nessa mesma época despertou sua simpatia pela Revolução Russa. Em seguida dedicou-se a escrever sobre o líder rebelde do levantamento camponês alemão do século XVI, Thomas Münzer (KROTZ, 2011).

Após o fim da Primeira Guerra Mundial passou a viver em Berlim. Em 1921 faleceria a sua primeira esposa, fato que o abalaria profundamente. Neste mesmo ano também ganharia a luz "Thomas Münzer: o teólogo da revolução" . Ao voltar-se para um evento ocorrido quatro séculos antes, poder-se-ia pensar que Bloch decidira dedicar sua atenção à reconstituição de algum evento do passado que, talvez, considerasse significativo. O engano não poderia ser maior. Logo à primeira página dessa instigante obra, ele informa: "não olhamos, aqui, de nenhum modo, para trás. Pelo contrário, engajamo-nos no passado enquanto ele é presente. E, deste modo, outros se transformam, os mortos retornam, seu gesto revive ainda em nós" (BLOCH, 1973, p. 1). Em suas páginas finais, Bloch lembra que "o mundo do poder econômico-político que nos rodeia [...] está carregado com uma dinâmica imanente para a destruição", inclusive, do "horizonte construtivo aberto ao oprimido, ao que foi enganado desde o tempo das guerras camponesas" (BLOCH, 1973, p. 206).O que restaria, então,aos oprimidos e aos que foram enganados senão resignar-se?Em resposta, porém,recorre ao seu otimismo militante, proclamando: "Por cima das ruínas e das esferas culturais arrasadas deste mundo, brilha altaneiro o espírito da indescaracterizável utopia” (BLOCH, 1973, p. 207). Sim, aqui reaparece a palavra-mágica, com a qual vaticina:

"E não apenas irromperá vida nova na velha realidade; mais ainda: há um campo aberto para transbordamentos, abertos nos ficam o mundo e a eternidade, o novo mundo do calor humano e da ruptura, da luz que jorra efusivamente do íntimo humano" (BLOCH, 1973, p. 207).

Essas duas obras, "Espírito da utopia”, publicada em 1918, e Thomas Münzer, publicada em 1921, Bloch as teria escrito sem nelas revelar maior influência do marxismo, posto que este ter-lhe-ia sido apresentado somente por volta de 1923 por seu amigo Lukács ${ }^{6}$.Trata-se,

\footnotetext{
4 “daß wir selig werden, daß es das Himmelreich geben kann, daß sich der evident eingesehene Trauminhalt der menschlichen Seele auch setzt, daß ihm eine Sphäre wie immer bestimmter Realität korrelativ gegenübersteht, das ist nicht nur denkbar, das heißt formal möglich, oder erfüllbar, das heißt objektiv möglich, sondern schlechterdings notwendig, weit entfernt von allen formalen oder realen Belegen, Beweisen, Erlaubnissen, Prämissen seines Daseins, aus der Natur der Sache a priori postuliert und demnach auch wirklich, das heißt von utopischer, intensiver Neigung genau gegebener, essentieller Realität” (BLOCH, 1918, p. 444).

5 Sobreseu “Thomas Münzer" ver, entre outros, Albornoz (2002), Infranca (2007) e Münster (1997).

${ }^{6}$ Entre outros, Lucien Pelletier (2015, p. 97) refere-se a "son adhésion au marxisme vers 1923 sous l’influence de l'ami Lukács".
}

PRACS: Revista Eletrônica de Humanidades do Curso de Ciências Sociais da UNIFAP 
evidentemente, de um rotundo equívoco? ${ }^{7}$.

Ao longo dos anos 1920, Bloch passaria temporadas na Itália e na França, mas continuaria tendo Berlin por referência principal. Em 1930 publicaria Spuren [= Vestígios]. Poucos anos depois conheceria Karola Piotrkowska, com quem se casou em Viena. Ela seria a mãe de seu único filho, Jan Robert [1937-2010] e companheira inseparável até o fim de sua vida. Em Paris conheceu e estabeleceu amizade com Walter B. S. Benjamin [1892-1940]. Ao voltar a Berlim também passou a relacionar-se com Theodor W. Adorno [1903-1969] e com o poeta e dramaturgo Bertold Brecht [1898-1956].

A chegada de Hitler ao poder levou-o a novo exílio. Ernst Bloch passou pela Suíça, Itália, Áustria, Iugoslávia, França e Tchecoslováquia. A partir de 1939 viveria nos EEUU, país no qual permaneceu por quase 11 anos. Não obstante, Bloch nunca conseguiu dominar satisfatoriamente o inglês nem, tampouco, interessar-se pela sociedade estadunidense. Contudo, o período de permanência nos EEUU, em grande parte do qual viveu recluso e mergulhado em seus estudos, permitiu que concluísse "O princípio esperança” (KROTZ, 2011).

Terminada a Segunda Guerra Mundial, Bloch aceitou o convite para ocupar uma cátedra na Universidade de Leipzig, pouco antes de constituir-se a República Democrática Alemã. É, portanto, aos 63 anos que Ernst Bloch tem, pela primeira vez, um trabalho regular, iniciando apenas então sua carreira de professor universitário. Durante o tempo em que atuou na Universidade de Leipzig, Bloch deu aulas, ajudou a fundar o periódico Deutsche Zeitschrift für Philosophie ["Revista Alemã para a Filosofia"] e dedicou-se à pesquisa em história da filosofia.

Em 1956, durante o famoso XX Congresso do Partido Comunista da União Soviética, seriam feitas revelações públicas acerca dos crimes cometido por Stalin. Convém recordar que, durante boa parte de sua vida, Bloch defendeu a União Soviética sob o estalinismo, deste se distanciando apenas tardiamente. No que diz respeito à sua atuação profissional, as coisas começaram a ir mal, coincidentemente, nessa época. Aos poucos, evidenciava-se crescente divergência entre suas ideias e a linha oficial do Partido. Sua atenção à dimensão subjetiva no processo do mundo, sua disposição de estudar Marx cientificamente a sério (e não repetir, insistentemente, chavões do marxismo vulgar), sua repulsa em relação ao culto à personalidade na vida pública e sua reivindicação de um comunismo autêntico, fundado no princípio da máxima liberdade, forneceram argumentos suficientes para os seus adversários - que, por isso,o rotularam de revisionista e,assim, contribuíram para que perdesse sua cátedra na Universidade de Leipzig em 1957. Como se não bastasse, no mesmo contexto sua esposa foi expulsa do Partido, diversos de seus estudantes e colaboradores foram encarcerados e vários de seus colegas tiveram que fugir para o exterior (KROTZ, 2011).

A surpreendente construção do muro, em Berlim, em 1961,levou a que Bloch se decidisse, então, a viver na Alemanha Ocidental. Em novembro daquele ano apareceria a oportunidade: quando já contava com 76 anos, Ernst Bloch aceitou o convite para tornar-se professor na Universidade de Tübingen, em Baden-Würtenberg. Bloch retribuiu como pôde: ofereceu, regularmente, um seminário por semestre, a despeito de sua debilidade física crescente, até às vésperas de sua morte (KROTZ, 2011).

Mas, a sua contribuição à Universidade de Tübingen ultrapassaria, de longe, sua dedicação

\footnotetext{
${ }^{7}$ Numa entrevista concedida em 1974 a Michael Löwy (1998, p. 300), Ernst Bloch afirmou: “conheci o marxismo muito cedo". Cedo o suficiente para tratar de Marx já em seu primeiro livro, cuja última parte tem o sugestivo título de Karl Marx, der Tod und die Apokalypse ["Karl Marx, a morte e o apocalipse”]. Sobre a influência do marxismo na obra de Bloch ver, entre outros, Haug (2012).
} 
às aulas proferidas. De suas 16 obras originais [ver figura], Bloch publicaria oito delas após 1961, ou seja, durante os 16 anos passados em Tübingen. Aqui caberiam considerações mais detalhadas sobre diversos livros que publicou antes e durante sua fase em Tübingen (HURBON, 1974). Como a seção a seguir será dedicada a "O princípio esperança" e na seguinte será conferida alguma atenção a Erbschaft dieser Zeit [“Herança desta época”], ambos publicados antes de 1961, tomar-se-ão, por sua representatividade, duas obras do período em que já se encontrava em Tübingen: Naturrecht und menschliche Würde ["direito natural e dignidade humana”], publicado em 1961, e Experimentum mundi, publicado em 1975.

Figura 1 - As obras de Ernst Bloch em fluxo sistemático

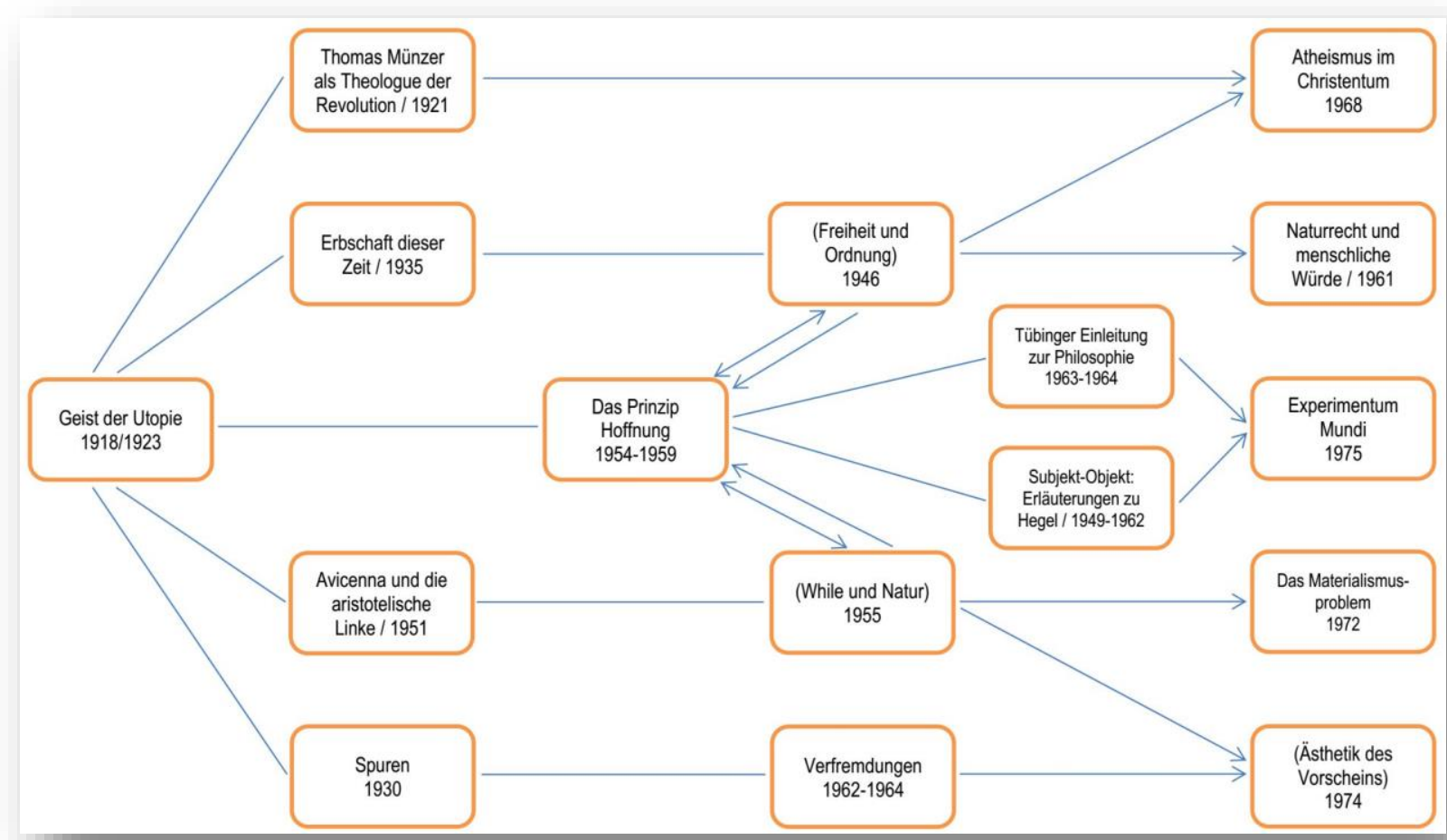

Fonte: adaptado de Schmied-Kowarzik (1995, p. 232).

$\mathrm{Na}$ primeira dessas obras, Bloch examinou, detidamente, as mais importantes doutrinas e tendências do Direito Natural ao longo da história, demonstrando como,a cada direito específico, corresponderam, objetivamente, a ideologia e os interesses das classes dominantes das diferentes épocas. Da perspectiva dos oprimidos, ofendidos e humilhados, o Direito Natural sempre foi - e continua sendo - o instrumento com o qual se tem preservado a ordem que tem favorecido as classes dominantes. Contra o Direito Natural restaria a dignidade humana, isto é, a disposição de superar a ordem prevalecente. Mas, e depois? Uma vez superado o Direito Natural (ao fim e ao cabo, o Direito Natural burguês), o que deveria ser posto em seu lugar? A isso Bloch responde:

“[uma] moral sem senhor e servo teria outras virtudes cardinais e não se institucionalizaria [...] [uma] moral livre de ideologia, ou seja, finalmente intencionada não-classista, é demasiadamente boa para ampliar o Direito Natural radical, é demasiadamente central para substituí-lo. O Direito Natural subjetivo radicalizado e sua exigência: cada um segundo suas capacidades, a cada um 
segundo suas necessidades, o Direito Natural objetivo radicalizado: solidariedade, estes bastam para o controle dos Direitos, eles bastarão concretamente" ${ }^{\text {. }}$

De maneira que em "Direito Natural e dignidade humana” está presente a ideia revolucionária de acordo com a qual a história - em seu sentido genuíno e substancial - gira em torno da superação das circunstâncias degradantes da vida humana, mas também da ordem que continuamente tem engendrado essas circunstâncias (NEGT, 2007, p. 47).

Em sua última obra publicada em vida - Experimentum mundi - Bloch voltaria a se debruçar mais demoradamente sobre a ética. A pergunta "qual moral em um mundo liberto da propriedade?" sugere duas respostas: uma primeira, que, evidentemente,teria que referir-se a um mundo sem propriedade ainda não alcançado; e uma segunda, que diz respeito à transição, isto é, ao caminho que pode levar a este mundo sem propriedade. De maneira que se está, de um lado, diante de uma "ética da solidariedade", não compatível com o mundo baseado na propriedade que ainda subsiste; de outro lado, porém, se está desafiado por uma "ética da transformação", uma exigência em relação ao mundo atual, como ele ainda existe, para que se possa vencer a exploração e a violência engendradas pela supremacia do capital e, finalmente,erigir uma ordem radicalmente fundada na solidariedade (ALBORNOZ, 2006b).

Ademais do exposto, conviria iluminar, ainda, mesmo que brevemente, três aspectos da vida e obra de Ernst Bloch que aqui podem ser considerados relevantes: as influências recebidas, as amizades contraídas e o legado deixado - as duas primeiras interatuando ao longo da vida, o último passível de ser avaliado globalmente somente depois.

Quanto ao primeiro de tais aspectos, é quase impossível, ainda mais nos limites de uma simples intervenção como esta, examinar, com maior precisão, as principais fontes sobre as quais repousa a obra de um autor reconhecidamente erudito e complexo como Ernst Bloch. Bastaria que se folheasse ao acaso um dos três volumes de "O princípio esperança" para se constatá-lo. De modo que, aqui, se pode, no máximo, indicar aquelas fontes cuja influência é mais saliente em seus escritos (PELLETIER, 2015). Entre diferentes estudiosos de sua obra são, frequentemente, lembrados os nomes de Friedrich Wilhelm Nietzsche[1844-1900] e Georg Simmel como inspiradores de suas ideias. No entanto, é pouco provável que constassem entre, digamos, as cinco mais significativas fontes. Mais relevantes parecem ser nomes como os de Immanuel Kant[1724-1804], Johann Christoph Friedrich von Schiller [17591805] e Johann Gottlieb Fichte[1762-1814]. Além destes, é certo que influência bem mais forte sobre Ernst Bloch foi a exercida por Georg Wilhelm Friedrich Hegel[1770-1831], a quem dedicou Subjekt-Objekt: Erläuterungen zu Hegel["Sujeito-objeto: explicações para Hegel”], opúsculo contendo mais de 500 páginas, com 25 capítulos distribuídos por três partes principais: der Zugang [“O acesso"], die Philosophie [“a filosofia”] e die Aufhebung ["a suspensão”] (BLOCH, 1971). Todavia, se o tema de toda a sua obra, anunciado já na primeira edição da primeira obra, em 1918, seria a utopia concreta, Ernst Bloch elegeria como seu interlocutor privilegiado a Karl Marx [1818-1883] - e Friedrich Engels [1820-1895]. Desde que entrou em contato com a obra de Marx, a influência de suas ideias revelar-se-ia decisiva em

\footnotetext{
8 "Moral ohne Herr und Knecht hätte andere Kardinaltugenden und würde nicht Institutionelles [...] Moral ideologiefreien Stils, nämlich endlich klassenlos intendierte, ist zu gut, um dem radikalen Naturrecht auszuweichen, zu zentral, um es zu ersetzen. Das radikale subjektive Naturrecht und sein Anspruch: jeder nach seinen Fähigkeiten, jedem nach seinen Bedürfnissen, das radikale Objektive Naturrecht: Solidarität, diese reichen zum Steuer der Rechte postulativ aus, werden konkret ausreichen" (BLOCH, 1977a, p. 269).
} 
cada um dos escritos de Bloch. Como se pode captar essa influência? A

"filosofia do possível [...] introduz o elemento transcendental no presente vivido e faz que o futuro [seja] obra humana. Se o futuro no pensamento utópico é antes de tudo um possível, a sua realização como provável e depois como fato dependerá justamente da práxis humana. Esta práxis como realização do possível é para Bloch entendida a partir das análises de Karl Marx em que se ligam a frieza da análise ao entusiasmo para um mundo melhor" (FURTER, 1974, p. 227).

Isso conduz ao segundo aspecto acima mencionado, as amizades que Bloch contraiu ao longo de sua vida. Ora, qualquer ser humano adulto - dependendo, por um lado, da maior ou menor disposição para interagir com outros adultos e, por outro, dos valores prevalecentes em cada sociedade - cultiva inúmeras amizades ao longo de sua vida, ainda mais se esta alcançar maior longevidade, como foi o caso da de Ernst Bloch. Por isso, ignoram-se, deliberadamente, listas de conhecidos e amigos que se encontram em diferentes estudos e referências sobre sua vida e obra, em favor da indicação de alguns poucos nomes que parecem ter tido presença mais significativa em sua biografia: o filósofo húngaro György Lukács, Walter Benjamin, o dramaturgo Bertolt Brecht e Theodor Adorno. Há, aqui, entre possíveis outros aspectos, dois aos quais convém conferir alguma atenção. Um, nada surpreendente, diz respeito ao fato de que estes e outros amigos eram intelectuais bastante próximos do marxismo. Outro aspecto que suscita alguma curiosidade é que as relações entre Bloch e seus amigos não eram, sempre, pacíficas. Ou seja, além de frequentes divergências de fundo filosóficodoutrinário, havia também eventuais conflitos de ordem pessoal, como, no caso, de sua amizade com Lukács (LÖWY, 1998; MÜNSTER, 1993; idem, 1997). Todavia, de certo ponto de vista, parece ter sido mais complexa a amizade de Bloch com Walter Benjamin, com o qual, talvez, tivesse tido maior afinidade (FURTER, 1974; MÜNSTER, 1993). Houve que afirmasse, a este respeito, que:

"As relações entre Benjamin e Bloch eram pessoalmente amigáveis, mas intensamente competitivas no plano intelectual. Em particular, o primeiro temia que Bloch plagiasse suas ideias de forma distorcida, ao passo que este percebia sua própria influência sobre Benjamin. Na verdade, as influências se exerciam provavelmente nos dois sentidos" (OSBORNE, 1997, nota 14, p. 111).

E, quanto ao terceiro aspecto, o que poderia ser chamado de legado de Ernst Bloch tende a ser considerado de diversos ângulos. Talvez se deva, inicialmente, recuperar o fio, tecido por Bloch em sua obra de estreia, que percorrerá todas as suas demais obras até alcançar a última delas. O leitmotiv do pensamento blochiano parece repousar na procura do que ainda não existe. Assim,

"Nossa busca não deverá se consumar na reorientação reflexiva em direção àquilo que já somos e sempre temos sido; de fato, encontramo-nos naquele ponto no qual nos estendemos proflexivamente em direção àquilo que ainda não somos, em direção ao que formulamos como possibilidade antecipável"’.

\footnotetext{
9 "Unsere Selbstsuche vermag sich nicht in der reflexiven Wendung auf das, was wir immer schon sind bzw. waren, zu erfüllen, sondern wir finden uns nur dort, wo wir uns proflexiv auf das voraus beziehen, was wir noch nicht sind, worauf wir uns aber als das uns Mögliche antizipierend entwerfen” (SCHMIED-KOWARZIK, 1995, p. 230-231).
}

PRACS: Revista Eletrônica de Humanidades do Curso de Ciências Sociais da UNIFAP 
Portanto, o leitmotiv - e, também, a novidade - da filosofia de Bloch, ancorada na moderna filosofia alemã, aponta para o futuro;mas, para um futuro alternativo ao presente existente, que rompe com esse fluxo que se projeta de um passado marcado por degradação, aviltamento e humilhação; um passado que, por ter sido o que foi, precisa ser radicalmente negado:

"La obra filosófica de Ernst Bloch, en su casi totalidad, estaba consagrada a ese ideal de una razón práctica renovada, humanista y revolucionária, que persigue infatigablemente el objetivo de la transformación del mundo en un mundo diferente, más habitable y más justo. Entre todos los pensadores que se ubican en la tradición filosófica que conduce de Kant a Hegel y de Hegel a Marx, Ernst Bloch es, sin duda, quin expresó de la manera más radical posible la idea de la resistencia moral de los intelectuales contra un mundo dominado por la injusticia, la violencia y la opresión, y que articuló este compromiso moral con una filosofía materialista dialéctica de la práxis que apuesta, en última instancia, mucho más a la antecipación de las imagines de deseo utópicas que a la crítica de la economía política, por más que considere, en tanto filósofo marxista, que esta última es absolutamente indispensable" (MÜNSTER, 2007, p. 162163).

A recepção à filosofia de Bloch acabaria sendo ambígua. De um lado, houve toda sorte de resistências contra o marxista e comunista que, ademais de optar por viver na ex-Alemanha Oriental, chegou a apoiar o estalinismo. De outro, não têm faltado tentativas de aplacar a radicalidade de sua obra por intermédio de interpretações idealistas, apolíticas e mesmo anticomunistas (KROTZ, 2011). E, no entanto, de sua obra salta um engajado militante que tomaria partido pelos que buscam fazer-se realidade nos sonhos e nos desejos não distorcidos dos seres humanos, isto é, nos desejos que apontam para a libertação humana. Porque é esses que se apresenta a oportunidade de romper com a violência da repetição histórica (NEGT, 2007, p. 49).

Em absoluta coerência com o que pensou - e escreveu - o militante Ernst Bloch apoiou com otimismo o movimento estudantil de 1968, e se solidarizou tanto com os dissidentes perseguidos dos países do chamado "socialismo real" quanto com as vítimas das ditaduras civis-militares latino-americanas. Sim, a sua identificação com o marxismo é inequívoca. Contudo, os marxismos oficiais e sectários, bem como a esquerda institucionalizada, têm óbvios problemas com sua filosofia utópica heterodoxa ${ }^{10}$. Foi agraciado por honras acadêmicas, mas também chegou a ser visto com desconfiança em face de sua familiaridade com movimentos esquerdistas e sua persistente crítica do capitalismo (KROTZ, 2011). Não importa: tanto quanto pensou o que coerentemente viveu, Ernst Bloch viveu com intensidade tudo aquilo que pensou.

\section{A UTOPIA EM DAS PRINZIP HOFFNUNG}

"Quem somos? De onde viemos? Para onde vamos? Que esperamos? O que nos espera?" (BLOCH, 2005, p. 1).

\footnotetext{
10 Desde suas primeiras obras ficara evidente que Ernst Bloch daria uma contribuição relevante para a análise marxista heterodoxa (FURTER, 1966); mas, com o tempo, também ficava evidente que ele se tornaria o herege mais produtivo do marxismo (NEGT, 2007).
}

PRACS: Revista Eletrônica de Humanidades do Curso de Ciências Sociais da UNIFAP 
De tudo o que Bloch pensou, Das Prinæip Hofnung [“O princípio esperança”] registra, certamente, o principal(ALBORNOZ, 1999). Esta obra monumental pode ser considerada não apenas um compêndio das formas e da história da esperança (BROWN, 2003), mas, mesmo, uma das grandes referências do pensamento emancipador do século XX (LÖWY, 2011). É sua mais extensa obra, porque aí fundamenta empiricamente a sua concepção filosófica (KROTZ, 2011). Embora não haja síntese possível para o que nela se encontra reunido, talvez se possa concordar que sua leitura revela existir:

“um só princípio: o de esperança. O mundo visa o 'bonun summum’. O mal é, portanto, só uma ameaça que se deve combater porque exige ser combatido. A felicidade de Bloch não exclui a possibilidade da infelicidade; mas esta não é necessária; é contingente" (FURTER, 1974, p. 40).

"O princípio esperança" é uma obra em três volumes, escrita entre 1938 e 1947 e revisada nos anos de 1953 e $1959^{11}$. O primeiro deles tem 433 páginas, que cobrem suas três partes iniciais. A primeira [relato] é intitulada "pequenos sonhos noturnos" e contém oito capítulos. A segunda parte [fundamentação] é intitulada "a consciência antecipadora" e contém 14 capítulos. A terceira parte [transição] é intitulada "imagens do desejo no espelho" e contém 10 capítulos (BLOCH, 2005). O segundo volume tem 477 páginas e cobre apenas a quarta parte [construção], intitulada "esboços de um mundo melhor". Esta contém 10 capítulos (BLOCH, 2006a). O terceiro volume tem 462 páginas e também cobre apenas uma parte, a quinta e última [identidade], intitulada "imagens do desejo do instante plenificado". Esta contém 13 capítulos (BLOCH, 2006b). Assim, se está diante de 55 capítulos, distribuídos por 1.372 páginas - aversão original tem 1.628 páginas. E, não obstante,por trás destes impressionantes números se encontra um tema bastante singelo: "os sonhos de uma vida melhor" (BLOCH, 2005, p. 21).

Como começar? Como ir adiante? O caminho será o de seguir alguns rastos deixados por Bloch na sequência em que escreveu "O princípio esperança”. E já no prefácio está indicada a direção a ser tomada. Com efeito, aí afirma que "todo ser humano, na medida em que almeja, vive do futuro [...] O futuro contém o temido ou o esperado e, estando de acordo com a intenção humana, portanto sem malogro, contém somente o esperado" (BLOCH, 2005, p. 14).E porque ocupar-se do futuro? Porque "o grandioso evento da utopia no mundo quase não foi esclarecido” (BLOCH, 2005, p. 16).

Entre as grandes categorias de "O princípio esperança" está a da "consciência antecipadora", sobre a qual se debruça na segunda parte do primeiro volume. Um passo inicial consiste em localizar a esperança na vida dos seres humanos:

"a esperança, este afeto expectante contrário à angústia e ao medo, é a mais humana de todas as emoções e acessivel apenas a seres humanos. Ela tem como referência, ao mesmo tempo, o horizonte mais amplo e mais claro. Ela representa aquele appetitus no ânimo que não só o sujeito tem, mas no qual ele ainda consiste essencialmente, como sujeito não plenificado" (BLOCH, 2005, p. 77 - itálico no original).

11 Os três volumes de "O princípio esperança" ganharam a superfície nos anos 1950, cabendo lembrar, novamente, que Bloch viveu, entre fins dos anos 1940 e início dos anos 1960, na Alemanha Oriental: o primeiro foi publicado em 1954 e o segundo, em 1955. "La publicación del terceiro es retenida con fines de presión política y no se realiza sino hasta 1959” (KROTZ, 2011, p. 60).

PRACS: Revista Eletrônica de Humanidades do Curso de Ciências Sociais da UNIFAP 
O tema da esperança, que confere título à sua opus magna, Ernst Bloch já o formulara na primeira edição de sua primeira publicação. Aí afirmara que a esperança não permite que sejamos destruídos, pois a alma humana tudo envolve, inclusive o que ainda não existe ${ }^{12}$.

A esperança em Bloch é um processo que compreende uma "tomada de consciência" em três momentos sucessivos: o primeiro se refere à carência, o segundo, à possibilidade e o terceiro, a umpossivel. A carência não é apenas fisiológica, um fato socioeconômico universal. Ela também é afetiva, sentimental, erótica, intelectual. E aponta para os sonhos. Sonhos? Sim, mas para "sonhos acordados", uma primeira aproximação à "utopia” (ALBORNOZ, 2006a; FURTER, 1974).

Figura 2 - Do sonho acordado à transformação

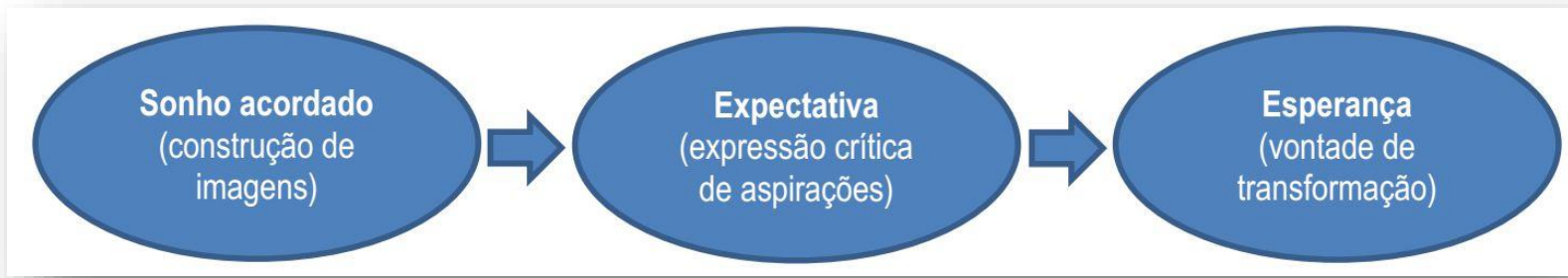

Fonte: inspirado em Furter (1974, p. 85).

E para que poderiam servir os "sonhos acordados"? Bloch responde:

"É antes de tudo o interesse revolucionário, com seu conhecimento de como está ruim o mundo e seu reconhecimento do quanto ele poderia ser bom como um outro mundo, que necessita do sonho desperto da melhoria do mundo" (BLOCH, 2005, p. 97).

Assim, os sonhos acordados apontam para a negação/superação deste mundo e anunciam outro mundo muito melhor. Alcançá-lo corresponde a,progressivamente, tomar consciência do que ainda não é: o bem supremo. E o que, concretamente, é o bem supremo? Bloch responde: "A variação mais elevada do bem supremo na esfera sociopolítica é a sociedade sem classes” (BLOCH, 2005, p. 172). Aí o summum bonnum político está identificado com o reino da liberdade, que apenas na sociedade sem classes pode ser conscientemente ${ }^{13}$ viabilizada como "último capítulo da história do mundo" (idem, p. 173; p. 298-300).

Em seguida ao da carência, o segundo momento do processo de tomada de consciência é o da possibilidade ${ }^{14}$. Em que consiste? Fundamentalmente, em "matéria dialética". Nas palavras de Bloch (2005, p. 204), "possiblidade real é apenas a expressão lógica para condicionalidade material do tipo suficiente por um lado e abertura material (inesgotabilidade do útero da matéria) por outro". Aqui se tem a entrada em cena da "matéria", em especial, da "matéria dialética", a qual expressa a potencialidade do real para a transformação. Assim, "a utopia concreta situa-se no borizonte de toda realidade. A possibilidade real envolve até o fim as tendências-latências

12 “die Hoffnung läßt uns nicht zuschanden werden. Denn die menschliche Seele umspannt alles, auch das Drüben, das noch nicht ist” (BLOCH, 1918, p. 443).

${ }^{13}$ Conscientemente, porque "o futuro não virá como fatalidade sobre o ser humano, mas o ser humano virá sobre o futuro e ingressará nele com o que é seu” (BLOCH, 2005, p. 196).

14 Para Albornoz (2006a, p. 97), “a possibilidade é a categoria das categorias”. 
dialéticas abertas" (idem, p. 221). No capítulo 18 - "os estratos da categoria possibilidade" Ernst Bloch distinguirá, então, entre o possível formal, o possível objetivo-factual, o possível conforme a estrutura do objeto real, e o possível objetivo-real - este último, o mais completo e profundo nível de possibilidade ${ }^{15}$. Assim, o terceiro momento do processo de tomada de consciência é o de um possível. Em que consiste este?

"Do mesmo modo que o real nos aparece sempre em movimento, apontando para além do que está total e maciçamente presente, assim a consciência antecipadora revela, em todos os níveis, o homem como um ser intencional e de tendência. À raiz deste duplo e correlativo movimento, encontra-se a categoria do possível" (FURTER, 1974, p. 112).

Dentre os demais capítulos desta segunda parte, consagrada à "consciência antecipadora", precisa ser destacado o capítulo 19 - "a transformação do mundo" -, no qual Bloch examina as teses de Marx sobre Feuerbach. Aí, ousadamente, propõe uma nova leitura das conhecidas teses, reordenando-as em três 'grupos' distintos: o grupo epistemológico [a contemplação e a atividade], o grupo histórico-antropológico [a auto-alienação e o verdadeiro materialismo] e o grupo teoria-práxis [comprovação e validação]. Para Ernst Bloch (2005, p. 274), a tese 11 é a mais importante, a que recebeu a formulação mais concisa. A sua releitura das teses indica que "a transformação sólida rumo ao reino da liberdade dá-se unicamente mediante um conhecimento sólido, com um domínio cada vez maior da sua obrigatoriedade" (idem, p. 277). Ou seja, a releitura blochiana das teses inspira um duplo movimento: o real precisa ser transformado um imperativo - a partir de sua adequada apreensão - a conditio sine qua.

Que balanço é possível fazer até aqui? O que, afinal, traduz a categoria "consciência antecipadora"? O mundo ruim que podemos conhecer convida a sonhar - acordado - com outro mundo, diferente que ainda não existe. Tomar consciência de que o mundo pode ser melhor revela um ser que ainda não é - em alemão: noch-nicht-Sein. É sobre ela, esta consciência de que o mundo pode ser melhor, que se apoia a esperança. Agora, "se o conteúdo do que se move no agora, do que foi tocado no aqui, se externasse positivamente, se fosse um 'Demora eternamente! És tão lindo!', então a esperança imaginada, o mundo esperado teria chegado ao seu alvo" (BLOCH, 2005, p. 286). É óbvio: o mundo esperado ainda não chegou ao seu alvo. Contudo, o "demora eternamente! És tão lindo" é a imagem do mundo melhor que, finalmente, pode despertar 'a mais humana de todas as emoções e acessível apenas a seres humanos'. E se a esperança forma a imagem de um mundo melhor,é porque ela rejeita, sim, ela nega o mundo ruim de que se vai tomando consciência. Aliás, "a esperança é uma contestação radical. É um não a uma situação inaceitável que estamos negando porque temos certeza, pela consciência antecipadora, de poder mudar a situação" (FURTER, 1974, p. 117) portanto, trata-se de uma categoria política (NEGT, 2007, p. 51).

Por falar em imagens, a terceira parte de "O princípio esperança" [transição] é, exatamente, dedicada às 'imagens do desejo no espelho'. Nela Bloch se debruça sobre as imagens antecipadas de um mundo melhor, por exemplo, em contos, filmes e peças de teatro. Mas, também aí adverte que pode haver engano e inautenticidade. Como distinguir, no anúncio de um mundo melhor, o que é autêntico e o que não é? $\mathrm{O}$ inautêntico já está revelado no 'fluxo da repetição indefinida de opressão, tirania e dominação’, enquanto o autêntico quer inter-

15 Para além desse formidável tratado sobre a possibilidade oferecido pelo capítulo 18 de "O princípio esperança”, ver também Bloch \& Ferenczi (1958) e Jung (2012).

PRACS: Revista Eletrônica de Humanidades do Curso de Ciências Sociais da UNIFAP 
rompê-lo e carregá-lo de esperança que leve a um mundo melhor. Com efeito, a:

"esperança está fundada no impulso humano para a felicidade e dificilmente poderá ser destruída, e com suficiente clareza ela sempre foi um motor da história. Ela o foi como expectativa e instigação para um objetivo positivamente visível, pelo qual importa lutar, e dá um impulso para frente no transcurso monótono do tempo" (BLOCH, 2005, p. 430).

A imagem de um mundo melhor pode despertar esperança nos seres humanos e, assim, leva-los não apenas a interromper o 'fluxo da repetição' como também a comprometê-los com a construção da alternativa que, finalmente, desemboque no 'Demora eternamente! És tão lindo!' E esta “atividade de construção, pela primeira vez na história da cultura, é moral, é a construção de um mundo sem exploração e sem sua ideologia” (BLOCH, 2005 p. 431).

A quarta parte [construção], intitulada "esboços de um mundo melhor" e constituída por 10 capítulos, ocupa, integralmente, o segundo volume (BLOCH, 2006a).

Aí se encontra o longo capítulo 36, dividido em três partes, que trata das utopias sociais. As suas primeiras linhas lembram que, no mundo real, capitalista, "poucos ricos vivem de muitos pobres". As utopias presentes nos contos de fada e em outros registros do passado constituem o "alegre prelúdio" de um mundo em que "as pessoas são iguais, a saber, vivem bem, não existe nem esforço nem trabalho” (BLOCH, 2006a, p. 29).

Nas páginas deste capítulo, indicação de estupenda erudição,comparecem, entre outros: Platão, Santo Agostinho e Francis Bacon, com destaque para Thomas Morus (BLOCH, 2006a, p. 70-77) e Campanella (idem, p. 77-83); assim como para Fichte (idem, p. 102-110), Owen e Fourier (idem, p. 111-116), Cabet e Saint-Simon (idem, p.116-123) e, também, Stirner, Proudhon e Bakunin (idem, p. 123-129). Do helenismo ainda é içada a utopia de Jâmbulo ["uma festa comunista e coletiva"] (idem, p. 46), enquanto da Idade Média tardia, a utopia de Joaquim de Fiore (idem, p. 64-70).

Um ponto especialmente interessante ganha atenção quando Bloch se refere às utopias cristãs. Aí é, por assim dizer, “desfeita a confusão” em torno da interpretação relativa a 'este mundo' e 'aquele mundo'. Ele adverte para o fato de que o sentido 'do reino de Deus', do paraíso,não é geográfico. Portanto, “este mundo” não é aqui, nem “aquele mundo” um céu no qual ingressará o pecador arrependido após sua morte. O sentido é original é, em definitivo, temporal. Portanto, por "este mundo" se deveria entender o agora, e por "aquele mundo", o futuro a ser buscado e atingido. Logo, "a ideia, com a contraposição desses conceitos, não é uma separação geográfica de realidade imanente e além, mas uma separação cronológica no mesmo cenário aqui existente. 'Aquele mundo' é a terra utópica, com um céu utópico acima dela" (BLOCH, 2006a, p. 55).

Mais adiante,ao atentar, com sua habitual perspicácia, as diversas contribuições, mais ou menos próximas das utopias cristãs, ele reitera sua disposição de recuperar o sentido original e correto delas. Em suas próprias palavras:

"A sociedade ideal se situava para Jâmbulo (como mais tarde para Morus, Campanella e com frequência para outros mais) em uma ilha longínqua, para Agostinho na transcendência. Contudo, para Joaquim [de Fiore] a utopia, como nos profetas, aparece exclusivamente na modalidade e na condição de futuro histórico. Os eleitos de Joaquim [de Fiore] são os pobres, que serão levados ao paraíso com o corpo vivo, não apenas como espírito. $\mathrm{Na}$ sociedade do terceiro Testamento não vivem mais classes” (BLOCH, 2006a, p. 65). 
Outra observação especialmente significativa é a que faz quando se debruça sobre as teses, tornadas públicas na primeira metade do século XIX, de Robert Owen [1771-1858]e Charles Fourier[1872-1837]. Em suas próprias palavras:

"quanto mais avançado economicamente um país, tanto mais horrorosa se tornava a situação de seus pobres [...] mesmo a pior época da privação camponesa medieval é suplantada pela miséria dos primeiros operários de fábrica [...] A tendência do tempo seria tornar os ricos cada vez mais ricos, os pobres cada vez mais pobres" (BLOCH, 2006a, p. 111).

Porque é significativa esta observação? Porque aí Bloch nota - o que tem escapado a numerosos estudiosos da sociedade, sobretudo, aos economistas - que o avanço das forças produtivas, impulsionado pelo capital, ao invés de aproximar os pobres de uma condição que lhe pudesse ser material e espiritualmente mais favorável, de fato, os afasta dela. A inferência, extraída do exame cuidadoso das teses de Owen e Fourier, de que os ricos se tornariam sempre mais ricos enquanto, os pobres continuariam empobrecendo cada vez mais, seria retomada por Karl Marx, a quem Ernst Bloch devotaria as páginas finais deste inspirado capítulo.

Mas, que contribuição poderia, justamente Marx,dar às 'utopias sociais’? Afinal,

"Marx investiu mais de nove décimos de seus escritos na análise crítica do agora, abrindo relativamente pouco espaço para adjetivações do futuro. Por esse motivo, Marx deu à sua obra [...] o nome de $O$ capital, e não, por exemplo, de Convocação para o socialismo" (BLOCH, 2006a, p. 175).

Mesmo tomando em conta este fato crucial - de que sua preocupação era com desvendar o que condicionava o tempo que lhe era contemporâneo -, Bloch (2006a, p. 176) defenderia que "toda a obra de Marx serve ao futuro". E, com Marx, este "futuro [seria] iluminado de forma materialista-histórica sob e a partir do passado e da atualidade, portanto, das tendências atuantes e persistentes, a fim de ser dessa maneira um futuro conscientemente moldável” (idem, p. 176). Ou seja, "um futuro compreendido, rumo ao qual finalmente [seria] possível viajar com mapa e bússola" (idem, p. 176).

Além de identificar a esperança na obra de Marx, ao referir-se a 'tendências' e recorrer à metáfora da 'viagem', Ernst Bloch também reconheceria a importância da noção de processo (BORGES, 1993), por isso, conferindo-lhe destaque. Todavia, é o que resulta do encontro entre esperança e processo - o 'realismo"16 - que, talvez, confira maior legitimidade ao seu argumento em defesa da utopia concreta. Como Bloch o desenvolve? Em suas próprias palavras:

"A utopia concreta vinculada ao processo existe nos dois elementos fundamentais da realidade compreendida em termos marxistas: em sua tendência, como tensão do que está na vez mas é tolhido; e em sua latência, como elemento correlato das possibilidades reais objetivas ainda não realizadas no mundo" (BLOCH, 2006a, p. 177).

Poucas linhas adiante, Bloch oferece uma síntese espetacular, em que se articulam os termos-chave de sua filosofia, inclusos aí 'esperança' e 'processo', que aí confluem solidamente

16 "A partir de Marx explicitam-se a inserção da mais audaz intenção no mundo que acontece, a unidade da esperança e da noção do processo, enfim, o realismo” (BLOCH, 2006a, p. 177).

PRACS: Revista Eletrônica de Humanidades do Curso de Ciências Sociais da UNIFAP 
para o seu argumento em favor da utopia concreta. Em suas próprias palavras:

"Assim como na alma humana raia o ainda-não-consciente que antes nunca havia sido consciente, assim raia no mundo algo ainda-não-originado: na dianteira do processo e da totalidade do mundo encontra-se essa frente e essa vasta categoria, ainda tão pouco compreendida, do novo. Seus conteúdos não são simplesmente os não manifestos, mas os não decididos, despontam na mera possibilidade real, trazem em si o perigo de um possível desastre, mas também a esperança da possível felicidade, ainda não comprometida e capaz de ser decidida por seres humanos. A tal ponto se estende a utopia, com tanto vigor essa matéria-prima se comunica a todas as atividades humanas, de forma tão essencial precisa estar contida em todo o conhecimento do ser humano e do mundo. Não existe nenhum realismo que o seria se abstraísse desse elemento mais forte na realidade, como realidade inconclusa" (BLOCH, 2006a, p. 178).

Aí está: "como realidade inconclusa". O novo ainda não foi decidido pelos seres humanos. Entre o 'ainda-não-consciente' e a utopia concreta há, por assim dizer, um fio de navalha, a possibilidade real, que, sim, pode resultar em catástrofe, mas que tende a realizar a esperança e abocar na felicidade.

E, então, Bloch finaliza este emblemático capítulo, tão previsível quanto surpreendentemente. Em suas próprias palavras:

"Pelo fato de os seres humanos conscientemente fazerem história pela primeira vez, dissipa-se a aparência daquele destino que foi produzido e inconscientemente transformado em fetiche pelas próprias pessoas na sociedade de classes. Destino é necessidade não decifrada, não dominada. Liberdade é necessidade dominada da qual desapareceu a alienação ${ }^{17}$ e da qual emerge verdadeira ordem, a saber, o reino da liberdade. A utopia tornada concreta fornece a chave para ele, para a ordem não-alienada na melhor de todas sociedades possíveis. Homo homini homo [O homem é o ser humano para o ser humano]: é isso, portanto, que significam os rudimentos de um mundo melhor, no que diz respeito à sociedade. E unicamente quando tiver ficado devidamente em ordem o relacionamento interpessoal, o relacionamento com o ser humano, o vivente mais poderoso, poderá ser iniciada uma intermediação realmente concreta com o não vivente mais poderoso: com as forças da natureza inorgânica" (BLOCH, 2006a, p. 178).

Aí, portanto, Bloch explicita seu otimismo, apostando na capacidade de os seres humanos rasgarem o véu que os vêm impedindo de decifrar a realidade na qual, até o presente, se encontram aprisionados. Desde a perspectiva da convivência dos seres humanos entre si, um mundo melhor passa a estar ao seu alcance, a utopia pode, agora, se concretizar em um 'reino de liberdade’. E, também, está dada a condição para, finalmente, transformar-se a convivência dos seres humanos com a natureza.

Nos capítulos seguintes são examinadas, por exemplo, as "utopias técnicas" [cap. 37], as "utopias arquitetônicas" [cap. 38], as "utopias geográficas" [cap. 39], temas - entre outros que complementam a quarta parte de seu "O princípio esperança", consagrada aos "esboços de um mundo melhor". Preparam para o passo derradeiro.

A quinta e última parte [identidade], intitulada "imagens do desejo do instante plenificado" e constituída por 13 capítulos, cobre, completamente, o terceiro volume (BLOCH, 2006b).

17 Já no primeiro volume de "O princípio esperança” havia uma importante referência sobre alienação (BLOCH, 2006a, p. 246). Mais sobre o assunto se encontra também em Bloch (1970).

PRACS: Revista Eletrônica de Humanidades do Curso de Ciências Sociais da UNIFAP 
É em seu sétimo capítulo [cap. 49 na sequência geral] que Ernst Bloch se debruça sobre a "vontade de chegar ao agora e ao ser-para-si plenos", lembrando ter sido Goethe quem dera:

“à aposta uma formulação jurídica precisa e utópica extremamente profunda: o 'Demora eternamente! És tão lindo!', dito para o instante, caracteriza a utopia do ser-ai[...] Em toda parte ainda está ausente o instante que proporciona o descanso, o ser-aí [Da-Sein] que torna objetivo a si mesmo ao demorar-se: na composição de uma terra paradisíaca, o 'demora-te' aparece, ele próprio, como terra" (BLOCH, 2006b, p. 98).

Este é, portanto, o momento em que já não será mais necessário ir adiante - assim como, evidentemente, retroagir: “A frase 'Demora eternamente! És tão lindo!' [...] constitui o paradigma metafísico da existência plena e sem qualquer além-mundo" (BLOCH, 2006b, p. 98). Este é, pois, o momento em que a 'utopia do ser-aí' terá, finalmente, alcançado a plenitude do agora e do para-si, em que ela terá coincidido com o instante do repouso absoluto, por isso, podendo, então, eternizar-se.

Mais adiante [cap. 53], Bloch - que, cedo, se declarara ateu - também se ocuparia do mistério religioso, inclusive, do que lhe acrescentou o cristianismo, em especial, o seu fundador. Sua 'releitura' da atuação de Jesus Cristo é digna de atenção, posto que ela põe a maioria das interpretações conhecidas de cabeça para baixo. Em suas próprias palavras:

"Um ser humano atuou aí de modo simplesmente bom; isso nunca havia ocorrido. Com uma tendência bem própria para baixo, na direção dos pobres e desprezados, mas de modo algum com ar de benfeitor. Com revolta para cima; não é possível ignorar os golpes de chicote nos cambistas e em todos 'que afligem os meus'. Não demorará muito mais até que a mesa seja virada e os últimos se tornem os primeiros” (BLOCH, 2006b, p. 344).

Aqui Ernst Bloch recupera uma 'imagem do desejo do instante plenificado' saída diretamente da biografia de quem questionara a ordem de Seu tempo, as hierarquias que vigoravam em Sua época. Mas, que imagem se configura desde a perspectiva emancipatória dos então desprezados e afligidos? A resposta é categórica: "A pobreza é a que está mais próxima da salvação; a riqueza a obstaculiza, tanto interior quanto exteriormente" (BLOCH, 2006b, p. 344).

Significaria isto que a pobreza seria $a$ condição para a emancipação? E, portanto, que a perpetuação de relações sociais que geram pobreza, de um lado, e pobreza, de outro, poderia ser tolerada ou, no mínimo, tomada com um dado?Bloch responde:

"a pobreza de forma alguma já é para Jesus uma porção da salvação, de maneira que ela não precisasse ser destruída. Em lugar algum se defende a pobreza habitual, imposta, miserável; o que se recomenda é a pobreza voluntária e o conselho neste sentido é dirigido somente aos opulentos, ao jovem rico" (BLOCH, 2006b, p. 344).

Os dois capítulos finais de seu "O princípio esperança", Bloch os dedica, respectivamente, ao "conteúdo último do desejo" [cap. 54], em que volta a debruçar-se sobre o "bem supremo', e à contribuição de Marx para a 'substância da esperança' [cap. 55]. No primeiro, adverte que o destino final - a ilha paradisíaca, o reino da liberdade... - ainda não está à vista. Em suas próprias palavras: "O próprio bem supremo é esse alvo ainda não formado, definitivamente significado na tendência do processo, definitivamente possível-real na latência do

PRACS: Revista Eletrônica de Humanidades do Curso de Ciências Sociais da UNIFAP 
processo" (BLOCH, 2006b, p. 409). Mas, então, propõe uma aposta definitiva na esperança, e esta é:

"A esperança do valor mais alto ou bem supremo, o ideal mais extremo que se pode conceber, que contém tanto o si-mesmo quanto o mundo acostumados e em equilíbrio um com o outro, de modo a indicar a todos os demais bens um rumo utópico" (BLOCH, 2006b, p. 419).

Estas poderiam ter sido as palavras de encerramento desta obra monumental. Mas, não são. As últimas palavras são consagradas à 'substância da esperança',à luz daquilo que Bloch qualifica como "espírito humanitário" de Marx. Com este, a transformação em direção ao 'reino da liberdade' requer "uma ação conjugada do 'coração', da consciência e, sobretudo, do conhecimento” (BLOCH, 2006b, p. 442).

O "espírito humanitário" se revelaria em Marx - segundo Bloch - "porque esse indignado sentia a si mesmo como ser humano", e "porque os demais são seres humanos como ele [Karl Marx], mas são tratados preponderantemente como cachorros”. A indignação de Marx sugeriria que "aqueles que [...] tratam [humanos como cachorros] nunca merecem [...] qualquer misericórdia, ao contrário; tolerá-los seria justamente agir de modo inumano em relação aos humilhados e ofendidos" (BLOCH, 2006b, p. 443). De forma que não se trata de "um espírito humanitário geral e abstrato', mas, ao contrário, um bastante concreto, "voltado para os únicos que necessitam dele. E juntamente com [Thomas] Münzer, Marx também lançou mão do açoite com que Jesus havia expulsado os cambistas do templo" (idem, p. 443).

O "espírito humanitário" de Marx desagua, como é sabido, na única proposição que poderia resultar de sua arguta análise: a de uma comunidade humana em que já não haja quem humilhe nem quem possa ser humilhado. A esta proposição volta-se Bloch, advertindo que, "caso se pretenda que a essência real dos conteúdos da esperança incida suficientemente na existência, ganhando chão, pés e mãos, então o local de entrada [...] chama-se sociedade sem classes - usque ad finem [até o fim]" (BLOCH, 2006b, p. 456).

Portanto, é com a 'sociedade sem classes' que principia, propriamente, a história; é com ela que o ser humano começa, realmente, a existir. Entretanto,

"o ser humano ainda existe, em toda parte, na pré-história, sim, tudo ainda se encontra numa condição anterior à criação do mundo como um mundo apropriado. A verdadeira gênese não se situa no começo, mas no fim, e ela apenas começará a acontecer quando a sociedade e a existência se tornarem radicais, isto é, quando se aprenderem pela raiz. Porém, a raiz da história é o ser humano trabalhador, produtor, que remodela e ultrapassa as condições dadas. Quando ele tiver apreendido a si mesmo e ao que é seu sem alienação, surgirá no mundo algo que brilha para todos na infância e onde ninguém esteve ainda: a pátria” (BLOCH, 2006b, p. 462).

É assim que Ernst Bloch conclui seu monumental "O princípio esperança”, considerado, como dito no início desta seção, um verdadeiro compêndio das formas e da história da esperança e uma das grandes referências do pensamento emancipador do século XX. Atente-se nesta conclusão para a extraordinária inversão que propõe na percepção do tempo: 'a verdadeira gênese se situa no fim’. Ou seja, a história humana começa lá aonde, afinal, se quer e se deve chegar: o reino da liberdade, a sociedade sem classes, a pátria, a utopia concreta. 


\section{A ATUALIDADE DA UTOPIA EM ERNST BLOCH}

A utopia foi um tema merecedor de considerável atenção ao longo de grande parte do conturbado século XX, sobretudo, até os anos 1970. Além de Ernst Bloch, dedicaram-lhe páginas preciosas tanto Martin Buber [1878-1965]e Karl Mannheim[1893-1947]quanto Herbert Marcuse [1898-1979]e Erich Fromm[1900-1980], entre inúmeros outros importantes nomes que ajudaram a moldar o pensamento desse período.

Martin Buber, por exemplo, atribuiu maior relevância - na construção de uma alternativa... - à disposição subjetiva do ser humano que aos condicionantes objetivos da realidade, afirmando que "para a utopia, tudo se acha submetido à vontade consciente do homem, podendo-se mesmo considerá-la imagem da sociedade esboçada como se não existissem outros fatores além dessa vontade" (BUBER, 1986, p. 18-19).

Já para Karl Mannheim (1968, p. 216), ao termo utopia está ligado um "tipo de orientação que transcende a realidade e que, ao mesmo tempo, rompe as amarras da ordem existente".Portanto, sua ênfase também recai mais sobre o 'tipo de orientação' - isto é,sobre o 'estado de espírito utópico', a disposição do indivíduo e/ou do grupo - do que sobre a realidade com a qual se quer romper. Há, assim, uma incongruência entre o 'estado de espirito utópico’ e a situação real. Mas, atenção: para Mannheim (1968, p. 216), são “utópicas somente aquelas orientações que, transcendendo a realidade, tendem, se se transformarem em conduta, a abalar, seja parcial ou totalmente, a ordem de coisas que prevaleça no momento".

Pode parecer curioso que Karl Mannheim não tivesse chegado a fazer grande referência a Ernst Bloch em seu Ideologie und Utopie. Contudo, há uma razão importante: o livro de Mannheim, publicado em 1960 nos EEUU [ideology and utopia: an introduction to the sociology of knowledge], do qual seria traduzida em 1968 a edição brasileira [ideologia e utopia], tivera sua primeira edição, em alemão, no longínquo ano de 1929. Até aquele momento, Bloch havia publicado apenas Geist der Utopie [1918/1923] e Thomas Münzer [1921]. De qualquer maneira, ao examinar "a primeira forma da mentalidade utópica: o quiliasma orgiástico dos anabatistas", Karl Mannheim (1968, p. 235 e seguintes) faz referência explícita ao Thomas Münzer de Ernst Bloch.

Herbert Marcuse (1969, p. 15), por sua vez, observou que "o conceito de utopia é um conceito histórico e se refere a projetos de transformação social cuja realização é considerada impossível". De forma que a ênfase, aqui, recai sobre a "impossibilidade de traduzir em fatos concretos o projeto de uma nova sociedade, na medida em que os fatores subjetivos e objetivos de uma dada situação social se opõem à sua transformação" (idem, p. 15). Ou seja, para Marcuse, o conceito de utopia remete à "imaturidade das condições sociais", que dificulta, se não impede, que projetos de transformação social sejam bem-sucedidos.

É interessante observar que Herbert Marcuse, que conhecera Bloch nos EEUU - para aquele país emigrara em 1934 e nele permanecera até o fim de sua vida, embora tivesse falecido em Starnberg/Alemanha, a 29 de julho de 1979, e suas cinzas estejam depositadas no Dorotheenstädischer Friedhof, em Berlin, desde 2003 - não faça qualquer referência a Ernst Bloch. Este, pode-se lembrar, viveu nos EEUU entre 1939 e 1948. E porque este fato tem relevância? Porque Marcuse publicou seu Das Ende der Utopie em 1967 e ignorou completamente a então já reconhecida obra de Bloch, embora fizesse referência à Ideologia e utopia de Karl Mannheim.

Por fim, também Erich Fromm contribuiu para uma concepção alternativa de sociedade, 
em especial, com seu "A revolução da esperança". Se, em diversas de suas obras, Fromm, reconhecido humanista, formulou críticas contundentes à sociedade capitalista, à qual associou tendências irracionais e inclinações destrutivas, tanto pelo estímulo ao consumo desenfreado quanto pelo impulso ao crescimento econômico sem limites, em várias delas também se dedicou a delinear uma opção autenticamente humana de convivência. Esta opção é, em termos blochianos, "utópica". E, para se dirigir a ela, cabe cultivar a "esperança".

Aqui se deve atentar para o fato de que Fromm reconheceu, em seu $A$ revolução da esperança, a contribuição de Bloch - ao contrário de Marcuse, a quem, por razões diversas, criticaria. Em nota de rodapé, Erich Fromm (1968) observou que "Ernst Bloch, em Das Prinæip Hoffnung, mais do que ninguém, recuperou o princípio profético da esperança no pensamento marxista". Quanto a Herbert Marcuse, a crítica de Fromm se dirigiu, fundamentalmente, contra seu pessimismo e sua desesperança. Na terceira nota ao segundo capítulo - intitulado A esperança -, Erich Fromm (1968) afirmou que, "em essência, Marcuse é um exemplo de um intelectual alienado que apresenta seu desespero pessoal como uma teoria de radicalismo".

O que se acabou de expor talvez seja suficiente para se dimensionar a relevância do futuro nos estudos de alguns dos representantes mais destacados do pensamento do século XX, até que este fosse cruelmente aprisionado pelo neoliberalismo nas frias masmorras do curto prazo. E, ao mesmo tempo,para reconhecer na obra de Bloch uma concepção inequivocamente original de utopia concreta, que parte do caráter inacabado do mundo e mobiliza a esperança para alcançar-se o reino da liberdade.

De inúmeras contribuições originais de Bloch que enriqueceram o conhecimento do século XX, algumas das quais já mencionadas nas páginas anteriores, cabe destacar ainda, especialmente, a sua "teoria da assincronia". De que se trata?

No ano de 1935, Ernst Bloch publicou Erbschaft dieser Zeit [“Herança desta época”], um instigante estudo sobre a trágica realidade então vivida pela Alemanha, marcada pela ascensão do nazifascismo, à luz não apenas de fatos genuinamente contemporâneos, mas também de elementos de diversos períodos já passados que se manifestavam naquele presente de horror, configurando uma ‘simultaneidade do temporalmente distinto' [Gleichreitigkeit des Ungleizeitigen] ${ }^{18}$.

Esta Alemanha dos primeiros decênios do século XX vivia as contradições de uma organização 'de cima para baixo'. Dado o caráter tardio do desenvolvimento do capitalismo naquele país, as diversas classes sociais coexistiam umas com as outras, mas cada qual tendo a experiência de seu próprio tempo, os integrantes de cada classe social vivenciando os acontecimentos históricos de uma perspectiva específica. Neste contexto, a consciência de classe era dificultada pela presença de "tempos latentes, míticos e arcaicos ou utópicos e antecipadores que se podem transmitir de uma classe a outra" (FURTER, 1974, p. 51). Daí se verificar uma 'consciência distorcida' dos pequenos burgueses, dos trabalhadores urbanos, do campesinato e de outros grupos sociais subalternos em face do nazi-fascismo. Ela pode ser explicada pela persistência, naquele presente, de resíduos ideológicos e econômicos de épocas anteriores, o que configuraria, para Ernst Bloch, a 'dialética da temporalidade desigual' [Dialektik der Ungleichreitigkeit] ${ }^{19}$.

Os primeiros vestígios de sua "teoria da assincronia", que Ernst Bloch formulou para analisar as contradições do capitalismo tardio na Alemanha nas primeiras décadas do século XX, já podiam ser

18 "Eine [...] wissenschaftsgeschichtliche Wurzel des Ungleichzeitigkeitstheorems [...] findet sich bei Ersnt Bloch. Insbesondere in seiner erstmals 1935 erschienenen Faschismusstudie 'Erbschaft dieser Zeit' breitete Bloch seine Überlegungen zur 'Gleichzeitigkeit des Ungleizeitigen’ aus” (LANDWEHR, 2012, p. 12; ver também FURTER, 1966).

${ }^{19}$ Cf. Bloch (1985a [1935]; idem, 1977b); ver também Schmied-Kowarzik (1995) e, sobretudo, Dietschy (2012). Segundo Münster (1997, p. 221), para Bloch era “assincrônico todo o pensar, opinar, agir, sentir [...] que não se encontra no ápice das contradições [...] não simultâneas do capitalismo da respectiva época, portanto uma consciência que se coloca de forma oblíqua, atravessada em relação às superestruturas culturais e espirituais que correspondem ao respectivo nível de desenvolvimento das forças produtivas e das condições de produção capitalista”.

PRACS: Revista Eletrônica de Humanidades do Curso de Ciências Sociais da UNIFAP 
identificados em suas obras iniciais - nomeadamente, Geist der Utopie, de 1918, e Thomas Münzer, de 1921). Contudo, como elaborada em Erbschaft dieser Zeit, a "teoria da assincronia" revela um esforço de Bloch com vistas a uma ampliação da tese formulada por Marx sobre o desenvolvimento desigual (SALINAS, 2007) e, ao mesmo tempo, à elaboração de uma nova concepção do tempo histórico (MACHADO, 2007; DAYTON, 1996).

A respeito desta última, é preciso enfatizar que o tempo histórico blochiano não é linear. Logo, o presente - o agora - não pode ser considerado mera expressão de continuidade do passado. Na realidade, este tempo histórico implica uma multiplicidade de diferenças espaço-temporais numa mesma contemporaneidade cronológica, articulando uma totalidade que não exclui o elemento ainda não caracterizado conscientemente ${ }^{20}$. Por isso, a análise que toma por referência a 'simultaneidade de tempos distintos" - fundamento da "teoria da assincronia" - também acaba por abarcar, inevitavelmente, inúmeros aspectos sociais, políticos e culturais das desigualdades temporais do desenvolvimento histórico (MACHADO, 2007, 57-64; DAYTON, 1996; THOMPSON, 2015).

Em face do exposto, como avaliar a atualidade de Ernst Bloch, em especial, de sua concepção de utopia concreta? Esta tarefa, evidentemente, não poderia ser limitada às linhas acima. E, no entanto, o que elas revelam parece suficiente para - em complemento ao que se expôs na seção dedicada ao seu "O princípio esperança" - identificar, no conjunto de sua obra, uma contribuição original, instigante e duradoura.É certo que, quem se ocupa com o futuro, como foi o caso de Bloch, passou a colher desprezo e esquecimento em face da progressiva valorização deliberadamente exagerada do curto prazo, sobretudo, após a emergência e generalização do neoliberalismo nos quatro cantos do planeta.Entre os inúmeros desprezados e esquecidos que enriqueceram o pensamento, com suas argutas análises sobre as possibilidades que se descortinavam para a humanidade no conturbado século XX, incluem-se Martin Buber, Karl Mannheim, Herbert Marcuse e Erich Fromm. É neste âmbito que se revelaria a originalidade de Bloch, por formular um instrumental - a "teoria da assincronia" - com o qual poderia examinar a simultaneidade do temporalmente distinto [Gleichzeitigkeit des Ungleizeitigen], como esta se manifestava, em meados dos anos 1930, na Alemanha sob o jugo do nazi-fascismo. Estava aí, portanto, em seu Erbschaft dieser Zeit ["Herança desta época"], de 1935, o instrumento que permitiria a Ernst Bloch avançar na construção de sua concepção de utopia concreta, partindo do caráter inacabado do mundo e mobilizando a esperança para buscar - usque ad finem o reino da liberdade.

\section{DIVERGÊNCIAS E MAL-ENTENDIDOS}

Não parece conveniente concluir este pequeno ensaio sem enfrentar alguns pontos controvertidos que dizem respeito à noção de utopia e, mesmo, ao conjunto da obra de Bloch. Entre os que aqui ainda estão a merecer alguma atenção, contam-se: a crítica de Habermas ao caráter supostamente especulativo do materialismo de Bloch; a presença incômoda da noção de progresso na obra de Bloch; e, em consequência, o seu possível desdém pelo mundo não europeu, subdesenvolvido; e, portanto, a impossibilidade de se tomar tanto a noção de utopia, em específico, quanto a obra de Bloch, em seu conjunto, como referência num contexto político-cultural tão peculiar como o da América Latina. Por último, resta a dúvida crucial: faz sentido ler Bloch no e desde o Brasil?

Quanto à crítica referente ao caráter supostamente especulativo do materialismo de Bloch, o que disse Habermas? Que "uma utopia que concebe de forma também utópica a

\footnotetext{
20 Portanto, também "não existe forçosamente um paralelismo nem aparentemente, nem profundamente, entre a evolução histórica de diferentes séries de eventos, entre diversos estratos que coexistem numa mesma sociedade com uma diferente percepção do tempo e, talvez, mesmo do espaço social” (FURTER, 1974, p. 50-51).
}

PRACS: Revista Eletrônica de Humanidades do Curso de Ciências Sociais da UNIFAP 
dialética de sua própria realização, não é tão concreta quanto pretende” (HABERMAS, 1980, p. 165). Para fundamentar sua 'acusação', ele aponta os vários graves "erros de interpretação de Bloch” (idem, p. 166). E, impiedosamente, afirma que:

"O materialismo de Bloch permanece especulativo, sua dialética do Iluminismo ultrapassa a dialética e se transforma em doutrina da potência. Usando uma linguagem metafórica - e um resíduo de metáfora adere sempre à utopia - poderíamos dizer que Bloch orienta seu pensamento muito mais para o desenvolvimento de um mundo que ele supõe genericamente em gestação que para a solução das contradições sociais existentes” (idem, p. 167-168).

Que o materialismo dialético de Bloch, que supostamente informaria a sua concepção de utopia, seja utópico, isto suscita pelos menos duas dúvidas atrozes - que Habermas acaba deixando no ar: primeiramente, o que ele quis dizer, aqui, com 'utópico'? Em segundo lugar, e mais importante: em que momento Bloch teria afirmado que sua concepção de dialética é seja lá o que isso signifique para Habermas ou, mesmo, para Bloch - utópica? Quanto aos erros referidos, eles se revelam não propriamente erros, mas, quando muito, pontos em relação aos quais parece haver alguma divergência. No entanto, o que mais incomodou a Habermas foi, mesmo, o caráter supostamente especulativo do materialismo blochiano. Foi o fato de que Bloch contrariou o apego inquestionado de Habermas ao Iluminismo, fundado no e base do - mundo que existiu até agora. Foi o sacrilégio de mobilizar a dialética para perquirir um mundo que ainda não é. Este foi “o” erro de interpretação de Bloch que não encontrou desculpa em Habermas.

Já o ponto que diz respeito à presença da noção de 'progresso' na obra de Bloch, que poderia ser considerada incômoda da perspectiva da periferia,inclusa aí a América Latina, ela, em princípio, reaproximaria o "filósofo da utopia" de um dos postulados centrais do Iluminismo - para a possível satisfação de Habermas. Que relevância, afinal, 'progresso' teve para Bloch?

É certo que este conceito frequentou a obra de Ernst Bloch. E não menos certo é que, tendo o seu uso tido larga disseminação, o seu significado deveria ser devidamente conhecido. Apesar disso, porém, em sua obra Bloch conferiu ao termo uma significação que dificilmente faria dele um ingênuo apologista de uma razão universal que a tudo e a todos deveria governar. É o que, por exemplo, se depreende da leitura de sua última obra, Experimentum Mundi, de 1975 - nela se encontra uma concepção de 'progresso' que já estava elaborada em sua Tübinger Einleitung zur Philosophie, de 1963/1964.Que concepção é esta? De acordo com Ernst Bloch, há que existir espaço para os diferentes povos e culturas do mundo no conteúdo objetivo ao qual diz respeito um 'progresso autêntico'. De forma que, nesta concepção de progresso, não há nem pode haver uma cultura-guia com tintura etnocêntrica nem, evidentemente,uma consciência de superioridade cultural. Há, todavia, convergência em relação a um ser humano autenticamente livre que, apesar de ainda não ser divisável em lugar algum, já se pode antecipar suficientemente em muitos lugares(MÜNSTER, 2007, 158163).Contudo, não apenas em suas últimas obras, mas mesmo em suas primeiras se manifesta esse cuidado com a significação de progresso. Ele se revela, por exemplo,em uma conhe-

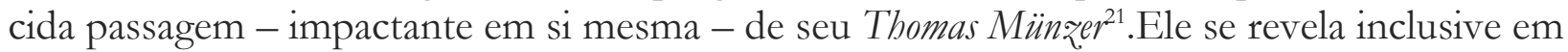

21 “A História não se apresenta [...] numa sucessão de imagens despedaçadas, nem, de nenhum modo [...] numa sólida epopeia do progresso e da Providência soteriológica, porém enquanto viagem dura e perigosa, paixão, peregrinação, errância, em busca da pátria perdida...” (BLOCH, 1973, p. 7).

PRACS: Revista Eletrônica de Humanidades do Curso de Ciências Sociais da UNIFAP 
sua primeira obra, quando afirmou que nada está pronto e acabado ${ }^{22}$. Nesses exemplos - e noutros mais - Ernst Bloch informa que o mundo e a humanidade que ele abriga estão inacabados. De forma que a tarefa à qual a humanidade deve se entregar é a de completar-se a si e ao mundo (BROWN, 2003). Portanto, há uma caminhada pela frente e o alvo é a utopia concreta. Mas, dado o pressuposto da assincronia, o caminho não poderia ser, de nenhum modo, universal-linear.

E quanto ao possível desdém de Bloch pelo mundo não europeu? É certo que "a obra de Bloch se refere sempre à Europa” (FURTER, 1974, p. 72). No entanto, o tema de Ernst Bloch não são os vencedores. São os derrotados, os oprimidos, os humilhados e ultrajados (NEGT, 2007, p. 49). Assim, embora tivesse a Europa como referência, a preocupação de Bloch sempre fora para com os vencidos - como os dissidentes do socialismo real e as vítimas das ditaduras latino-americanas. Por isso, cabe considerar a sua obra em um contexto mais amplo: "o contexto planetário [abarcando] uma parte do mundo que está cansada de estar 'subdesenvolvida'..." (FURTER, 1974, p. 72).

Do mundo subdesenvolvido, considere-se, em especial, o bastante peculiar contexto da América Latina. Apesar de sua imensa diversidade sociocultural, tem-se pensado a realidade do subcontinente com os métodos e as categorias produzidos no velho mundo e, mais recentemente, nos EEUU. Operaria a obra de Bloch como mais um recurso a oferecer aos nativos uma compreensão distorcida tanto de seu ambiente quanto de si mesmos? Apesar dos riscos envolvidos, parece haver possibilidades de se estabelecer uma interlocução respeitosa entre Ernst Bloch e o pensamento crítico latino-americano - incluam-se aí a filosofia da libertação, a teologia da libertação, a sociologia da libertação... -, se, com efeito, sua obra puder ser empregada, na América Latina, como uma referência ético-material de vida, uma ética a partir das vítimas (VIEIRA, 2007). Este diálogo respeitoso, aliás, já tem alguns bons antecedentes. Mais recentemente, Ana Cecilia Dinerstein (2015) explicitou sua 'afinidade eletiva' com a obra de Ernst Bloch, a partir da identificação de pontos de convergência entre sua filosofia e as práticas dos movimentos que lutam por autonomia na América Latina.

É evidente que as possibilidades de uma aproximação de Bloch com a América Latina não se traduziriam como um 'pensar' desde a Europa e um 'agir' no subcontinente. Inclusive, porque o filósofo da utopia considerava a luta política, na qual se engajou vivamente,como o único caminho que pode levar à criação de um mundo em que os seres humanos finalmente se reconhecem em seus sonhos e esperanças (NEGT, 2007, p. 54).

E quanto, especificamente, ao Brasil? Faz sentido ler Bloch no e desde o Brasil? Também aqui existem bons antecedentes nos notáveis esforços, já referidos, de Suzana Albornoz. De forma que parece haver possibilidades de estabelecer-se uma interlocução de mútuo respeito entre Ernst Bloch e o pensamento crítico brasileiro - inclua-se aí o que se quiser - pela mesma conhecida razão de que sua obra pode ser tomada como referência ética a partir dos vencidos.Enfim, um diálogo respeitoso entre a obra de Bloch e o pensamento crítico latinoamericano, e brasileiro, não apenas tende a ser profícuo para as partes, mas, dada a virulência com que o neoliberalismo ressurgiu no subcontinente, mostra-se mesmo necessário para o último.

22 Em suas próprias palavras: "nichts ist fertig, nichts ist bereits geschlossen, nichts ist innen gediegen" (BLOCH, 1918, p. 444) - na segunda edição, a última frase passou a ter a redação: “nichts ist zentral gediegen” (BLOCH, 1985b, p. 346).

PRACS: Revista Eletrônica de Humanidades do Curso de Ciências Sociais da UNIFAP 


\section{CONCLUSÃO}

O propósito que animou esta breve intervenção foi, cabe lembrar ainda uma vez, resgatar o sentido da utopia na obra de Ernst Bloch, em especial, a noção de utopia que se encontra em seu "O princípio esperança", examinando sua atualidade no presente contexto de exacerbação da barbárie.

Como deve ter ficado evidente, Ernst Bloch não é apenas o filósofo/pensador da utopia (BROCA, 2014; KROTZ, 2011; VIEIRA, 2007), talvez o responsável por "una de las pocas grandes filosofías sistemáticas del siglo XX” (HOLZ, 2007, p. 25). Ele também é - para o benefício do pensamento crítico latino-americano, e brasileiro -, integralmente, um filósofo político da resistência (NEGT, 2007, p. 48).

Como também deve ter ficado evidente, a obra de Ernst Bloch revela não apenas ser atualíssima, como inclusive se inscreve entre aquelas referências que atravessam os tempos. Afinal, ela desce das estantes para despertar na alma dos oprimidos, humilhados e ultrajados - da América Latina e de qualquer canto do mundo - o ainda-não-consciente, para neles instilar o 'ainda-não-ser', para neles acender a esperança crítica com que podem concluir sua viagem em direção utopia concreta (APOLINÁRIO, 2008, p. 48).

Equivocam-se, pois, os que se apegam ao mundo que tem existido até agora. Ernst Bloch lembra a estes que "a verdadeira gênese não se situa no começo, mas no fim”. Porque a história humana autêntica principia, realmente, lá aonde se quer e se deve chegar: o reino da liberdade, a sociedade sem classes, a pátria, a utopia concreta. Aí, então, será possível suspirar: 'Demora eternamente! És tão lindo!'

\section{REFERÊNCIAS}

ALBORNOZ, Suzana. O enigma da esperança: Ernst Bloch e as margens da história do espírito. Petrópolis: Vozes, 1999.

ALBORNOZ, Suzana. Violência ou não violência: um estudo em torno de Ernst Bloch. Santa Cruz do Sul: Ed. Unisc, 2002.

ALBORNOZ, Suzana. Ética e Utopia: ensaio sobre Ernst Bloch. 2 ed. Porto Alegre: Movimento; Santa Cruz do Sul: Ed. Unisc, 2006.

ALBORNOZ, Suzana. Os ideais morais segundo Ernst Bloch: a união de Dioniso e Apolo. Humanas, 28 (2), p. 177-200, 2006.

APOLINÁRIO, José Antônio F. A práxis no pensamento utópico de Ernst Bloch. Cadernos de Ética e Filosofia Política, N. 13, p. 43-56, 2008.

BLOCH, Ernst. Geist der Utopie. München; Leipzig: Verlag von Duncker \& Humblot, 1918.

BLOCH, Ernst. Entfremdung, Verfremdung: alienation, estrangement. The Drama Review TDR, 15 (1), p. 120-125, 1970.

BLOCH, Ernst. Subjetk-Objekt: Erläuterungen zu Hegel (= Suhrkamp Taschenbuch, 12). Frankfurt am Main: Suhrkamp, 1971.

BLOCH, Ernst. Thomas Münzer: teólogo da revolução (= Biblioteca Tempo Universitário, 34). Trad. Vamireh Chacon; Celeste A. Galeão. Rio de Janeiro: Tempo Brasileiro, 1973.

BLOCH, Ernst. Naturrecht und menschliche Würde. Frankfurt am Main: Suhrkamp, 1977a.

BLOCH, Ernst. Nonsynchronism and the obligation to its dialectics. New German Critique, N. 11, p. 22-38, 1977 b.

BLOCH, Ernst. Erbschaft dieser Zeit. Frankfurt am Main: Suhrkamp, 1985a [1935].

BLOCH, Ernst. Geist der Utopie [zweite Fassung]. Frankfurt am Main: Suhrkamp, 1985b. 
BLOCH, Ernst. O princípio esperança I. Trad. Nélio Schneider. Rio de Janeiro: Ed. UERJ; Contraponto, 2005.

BLOCH, Ernst. O princípio esperança II. Trad. Werner Fuchs. Rio de Janeiro: Ed. UERJ; Contraponto, 2006a.

BLOCH, Ernst. O princípio esperança III. Trad. Nélio Schneider. Rio de Janeiro: Ed. UERJ; Contraponto, 2006b.

BLOCH, Ernst; FERENCZI, Rose-Marie. Sur la catégorie de la possibilité. Revue de Métaphysique et de Morale, 63 (1), p. 56-82, 1958.

BORGES, Anselmo. Ernst Bloch: a esperança ateia contra a morte. Revista Filosófica de Coimbra, 2 (4), p. 403-426, 1993.

BROCA, Sebastien. Ernst Bloch, du temps messianique a l'utopie concrete. Encyclo: revue de l'ecole doctorale ED 382, p. 143-151, 2014 <https://hal.archives-ouvertes.fr/hal01154790/document>.

BROWN, Judith. Ernst Bloch and the utopian imagination. Eras Journal, N. 5, nov. 2003 $<$ http://artsonline.monash.edu.au/eras/ernst-bloch-and-the-utopian-imagination $>$.

BUBER, Martin. O socialismo utópico. Trad. Pola Civelli. 2 ed. São Paulo: Perspectiva, 1986.

DAYTON, Tim. Reclaiming utopia: the legacy of Ernst Bloch. Against the Current, N. 62, mai.jun./1996 < https://solidarity-us.org/site/node/2415>.

DINERSTEIN, Ana Cecilia. The politics of autonomy: the art of organising hope.Hampshire: Palgrave Macmillan, 2015.

DIETSCHY, Beat. Ungleichzeitigkeit, Gleichzeitigkeit, Übergleichzeitigkeit. In: DIETSCHY, Beat; ZEILINGER, Doris; ZIMMERMANN, Rainer E. (org.) Bloch-Wörterbuch: Leitbegriffe der Philosophie Ernst Blochs. Berlin: De Gruyter, p. 589-633, 2012.

FERNÁNDEZ, Victor Ramiro. Desde el laboratorio neo-desarrollista a la resurgencia neoliberal: una revisión creativa del 'doble movimiento' polanyiano en América Latina. Revista Estado y Políticas Públicas, No 7, p. 21-47, 2016.

FROMM, Erich. The revolution of hope: toward a humanized technology. Nova Iorque: Harper \& Row, 1968.

FURTER, Pierre. Utopie et marxisme selon Ernst Bloch. Archives de Sociologie des Religions, 21 (1), p. 3-21, 1966.

FURTER, Pierre. A dialética da esperança: uma interpretação do pensamento utópico de Ernst Bloch. Rio de Janeiro: Paz e Terra, 1974.

HABERMAS, Jürgen. Ernst Bloch: um Schelling marxista. In: FREITAG, B.; ROUANET, S. P. (org.) Habermas: sociologia (= Grandes Cientistas Sociais, 15). São Paulo: Ática, p. 151-168, 1980. HAUG, Wolfgang Fritz. Marxismus. In: DIETSCHY, Beat; ZEILINGER, Doris; ZIMMERMANN, Rainer E. (org.) Bloch-Wörterbuch: Leitbegriffe der Philosophie Ernst Blochs. Berlin: De Gruyter, p. 247-265, 2012.

HOLZ, Hans Heinz. Ernst Bloch: entremundo y umbral de época. In: VEDDA, Miguel (org.) Ernst Bloch: tendencias y latencias de un pensamiento. Buenos Aires: Herramienta, p. 23-45, 2007.

HURBON, Laënnec. Ernst Bloch: utopie et esperance. Paris: Les Éditions do Cerf, 1974.

INFRANCA, Antonino. Para una lectura estética del Thomas Münzer de Ernst Bloch. In: VEDDA, Miguel (org.) Ernst Bloch: tendencias y latencias de un pensamiento. Buenos Aires: Herramienta, p. 111-118, 2007.

JUNG, Werner. Möglichkeit. In: DIETSCHY, Beat; ZEILINGER, Doris; ZIMMERMANN, Rainer E. (org.) Bloch-Wörterbuch: Leitbegriffe der Philosophie Ernst Blochs. Berlin: De Gruyter, p. 302310, 2012.

KROTZ, Esteban. Introducción a Ernst Bloch (a 125 años de su nacimiento). Enclaves del Pensamiento, 5 (10), p. 55-73, 2011. 
LANDWEHR, Achim. Von der 'Gleichzeitigkeit des Ungleichzeitgen'. Historische Zeitschrift, 295 (1), p. 1-34, 2012.

LÖWY, Michael. Entrevista com Ernst Bloch. In: LÖWY, Michael. A evolução política de Lukács: 1909-1929. Trad. H. H. A. Mello; A. F. Martins; G. M. Brandão. São Paulo: Cortez, p. 295305, 1998.

LÖWY, Michael. Marxismo y religión en Ernst Bloch. Viento Sur, N. 114, p. 38-42, 2011.

MACHADO, Carlos Eduardo J. Sobre herencia de esta época de Ernst Bloch. In: VEDDA, Miguel (org.) Ernst Bloch: tendencias y latencias de un pensamiento. Buenos Aires: Herramienta, p. 55-72, 2007.

MANNHEIM, Karl. Ideologia e utopia. Trad. Sérgio M. Santeiro. Rio de Janeiro: Zahar, 1968.

MARCUSE, Herbert. O fim da utopia. Trad. Carlos Nelson Coutinho. Rio de Janeiro: Paz e Terra, 1969.

MÜNSTER, Arno. Ernst Bloch: filosofia da práxis e utopia concreta. São Paulo: Ed. Unesp, 1993.

MÜNSTER, Arno. Utopia, messianismo e apocalipse nas primeiras obras de Ernst Bloch. Trad. Flávio B. Siebeneichler. São Paulo: Ed. Unesp, 1997.

MÜNSTER, Arno. Günther Anders y Ernst Bloch: del malentendido a la polémica? In: VEDDA, Miguel (org.) Ernst Bloch: tendencias y latencias de un pensamiento. Buenos Aires: Herramienta, p. 147-167, 2007.

NEGT, Oskar. Andar erguido y la coproductividad de la naturaleza. In: VEDDA, Miguel (org.) Ernst Bloch: tendencias y latencias de un pensamiento. Buenos Aires: Herramienta, p. 47-54, 2007.

OSBORNE, Peter. Vitórias de pequena escala, derrotas de grande escala: a política do tempo de Walter Benjamin. In: BENJAMIN; Andrew; OSBORNE, Peter (org.) A filosofia de Walter Benjamin: destruição e experiência. Trad. Maria Luiza X. A. Borges. Rio de Janeiro: Jorge Zahar, p. 72 121, 1997.

PELLETIER, Lucien. La formation de la philosophie d'Ernst Bloch à partir de la mystique de maître Eckart. Laval theologique et philosophique, 71 (1), p. 97-132, fev. 2015.

SALINAS, Martin. Hacia un realismo abierto: la categoria de asincronia en la teoría literaria de Ernst Bloch. In: VEDDA, Miguel (org.) Ernst Bloch: tendencias y latencias de un pensamiento. Buenos Aires: Herramienta, p. 169-178, 2007.

SCHMIED-KOWARZIK, Wolfdietrich. Ernst Bloch: Suche nach uns selbst ins Utopische. In: FLEISCHER, Margot (Org.) Philosophen des 20. Jahrhunderts: Eine Einführung. Darmstadt: Wissenschaftliche Buchgesellschaft, p. 216-240, 1995.

THOMPSON, Peter. Ernst Bloch, Ungleizeitigkeit, and the philosophy of being and time. New German Critique, 42 (2), p. 49-64, 2015.

VIEIRA, Antonio R. Princípio esperança e a "herança intacta do marxismo em Ernst Bloch". Anais do V Colóquio Internacional Marx Engels, Campinas: Unicamp, 2007.

WEIGAND, Karl-Heinz. Ernst Bloch: une introduction. Revista Filosófica de Coimbra, 7 (13), p. 71-82, 1998. 